\title{
METODE PATH ANALYSIS: HUBUNGAN FAKTOR INTERNAL DAN EKSTERNAL REMAJA PUTRI DENGAN PERILAKU PENCEGAHAN KANKER SERVIKS
}

\author{
Path analysis method: relationship between internal - external factors and \\ cervical cancer prevention behavior among of adolescent girls
}

\author{
Santy Irene Putri ${ }^{1 *}$, Maria Paula Marla Nahak ${ }^{2}$ \\ ${ }^{1}$ Program Studi D-IV Bidan Pendidik Universitas Tribhuwana Tunggadewi, Malang \\ ${ }^{2}$ Fakultas Keperawatan Universitas Citra Bangsa, Kupang, Nusa Tenggara Timur \\ *E-mail: santyirene@ gmail.com
}

Naskah masuk 21 Oktober 2020; review 26 Oktober 2020; disetujui terbit 29 Desember 2020

\begin{abstract}
Background: Cancer is the leading cause of death in women. Cervical cancer ranks second after breast cancer, which is most often found in Indonesian women. Efforts to prevent cervical cancer in adolescents are still lacking, one of which is due to limited knowledge.

Objective: This study aimed to analyze the relationship between internal and external factors of adolescents and the behavior of cervical cancer prevention.

Methods: This study was an observational analytic study with a cross-sectional design. It was conducted in the Midwifery Study Program Unitri, Malang and the Faculty of Nursing, Universitas Citra Bangsa Kupang, East Nusa Tenggara. The dependent variable was cervical cancer prevention. The independent variables were the age of first sexual intercourse, parental support, peer-education, culture, attitudes, and knowledge.

Results: The behavior of cervical cancer prevention was directly affected by knowledge $(b=0.16 ; S E=0.07$; $p=0.019)$, attitude ( $b=0.23 ; S E=0.07 ; p=\langle 0.001)$, parental support ( $b=0.12 ; S E=0.05 ; p=0.027)$, and culture $(b=0.15 ; S E=0.06 ; p=0.020)$. Knowledge was affected by peer-education $(b=0.19 ; S E=0.07 ; p=0.008)$. Attitudes were affected by age of first sexual intercourse ( $b=-0.12 ; S E=0.06 ; p=0.053$ ).

Conclusion: Knowledge, attitude, parental support, and culture directly affected the behavior of cervical cancer prevention.
\end{abstract}

Keywords: behavior, cervical cancer prevention, adolescent girls

\begin{abstract}
Abstrak
Latar belakang: Kanker merupakan penyebab kematian terbanyak pada perempuan. Kanker serviks menempati urutan kedua setelah kanker payudara yang paling banyak dijumpai pada perempuan Indonesia. Upaya pencegahan kanker serviks pada remaja putri masih kurang salah satunya disebabkan oleh pengetahuan yang masih terbatas.

Tujuan: Penelitian ini bertujuan untuk mengetahui hubungan faktor internal dan eksternal remaja putri dengan perilaku pencegahan kanker serviks.

Metode: Penelitian ini merupakan penelitian analitik observasional dengan desain studi cross-sectional. Penelitian ini dilaksanakan di Prodi Kebidanan Universitas Tribhuwana Tunggadewi Malang dan Fakultas Keperawatan Universitas Citra Bangsa Kupang Nusa Tenggara Timur. Variabel dependen yaitu perilaku pencegahan kanker serviks. Variabel independen yaitu usia pertama kali berhubungan seksual, dukungan orang tua, dukungan teman sebaya, budaya, sikap, dan pengetahuan.

Hasil: Perilaku pencegahan kanker serviks dipengaruhi secara langsung oleh pengetahuan $(b=0,16$; $S E=0,07$; $\mathrm{p}=0,019)$, sikap $(\mathrm{b}=0,23 ; \mathrm{SE}=0,07 ; \mathrm{p}=<0,001)$, dukungan orang tua $(\mathrm{b}=0,12 ; \mathrm{SE}=0,05 ; \mathrm{p}=0,027)$, dan budaya $(b=0,15 ; \mathrm{SE}=0,06 ; \mathrm{p}=0,020)$. Pengetahuan dipengaruhi oleh dukungan teman sebaya ( $\mathrm{b}=0,19 ; \mathrm{SE}=0,07 ; \mathrm{p}=0,008)$. Sikap dipengaruhi oleh usia berhubungan seksual pertama kali $(b=-0,12 ; \mathrm{SE}=0,06 ; \mathrm{p}=0,053)$.

Kesimpulan: Pengetahuan, sikap, dukungan orang tua, dan budaya mempengaruhi perilaku pencegahan kanker serviks secara langsung.
\end{abstract}

Kata kunci: pencegahan kanker serviks, perilaku, remaja putri 


\section{PENDAHULUAN}

Penyakit kanker menjadi masalah penyakit kronis utama di negara maju dan berkembang, bahkan di negara miskin. ${ }^{1}$ Penyakit tersebut tidak hanya menjadi beban kesehatan namun juga menjadi beban ekonomi serta sosial. Penyakit ini merupakan pandemi global yang yang terjadi di negara maju tetapi meningkat dengan pesat di negara-negara berpenghasilan rendah dan menengah karena sumber daya untuk melaksanakan upaya pencegahan, diagnosis dan pengobatan terbatas atau tidak ada. ${ }^{2}$

Setiap tahun ditemukan sekitar 528.000 kasus baru kanker, dan kanker serviks pada perempuan menempati urutan keempat di seluruh dunia, setelah kanker payudara, kolorektal, dan paruparu. Terdapat perbedaan kasus kanker serviks di negara maju dan negara berkembang, dimana kasus kanker serviks berkurang secara signifikan pada negara maju sejak penerapan program skrining yang dapat berjalan secara efektif. Namun, kasus kanker serviks di negara berkembang tidak mengalami penurunan karena kesulitan dalam melaksanakan program skrining yang berbasis sitologi. ${ }^{3}$ Sebagian besar $(85 \%)$ kasus kanker serviks juga terjadi di negara miskin. Hampir sembilan dari sepuluh kematian (87\%) akibat kanker serviks terjadi di wilayah tersebut. $^{4}$

Data lain menunjukkan bahwa kanker payudara dan kanker serviks merupakan kanker yang paling sering terjadi pada perempuan di negara berkembang. ${ }^{5}$ Perkiraan untuk masing-masing kasus yaitu kanker payudara 882.900 kasus baru per tahun dan kanker serviks 444.500 kasus baru per tahun. Lebih dari 324.300 perempuan menderita kanker payudara dan 230.400 penderita kanker serviks meninggal setiap tahun. Secara global angka kejadian akibat kanker serviks diproyeksikan terus meningkat menjadi 720.415 kasus baru dan 394.905 kasus kematian pada tahun 2025. Peningkatan tersebut diprediksi secara khusus untuk negara-negara dalam cakupan Global Alliance for Vaccines and Immunisation (GAVI), yang mewajibkan tersedianya dana pendamping, dengan perkiraan peningkatan 58\% jumlah kasus baru dan $63 \%$ jumlah kematian. ${ }^{6}$

Penting untuk meningkatkan kesadaran pada perempuan dengan faktor risiko kanker serviks, yaitu dengan menekankan pentingnya tes pap smear secara teratur dan untuk menjamin tindak lanjut yang memadai, misalnya jika ditemukan hasil pap smear yang abnormal, maka dapat dilakukan pengulangan pap smear pada beberapa minggu setelahnya dan dukungan emosional yang meliputi kepedulian dan perhatian terhadap remaja perempuan untuk melakukan pencegahan kanker serviks apabila diperlukan. Selain itu, perlu menumbuhkan kesadaran pada orang tua tentang keuntungan dari vaksin anti- human papillomavirus (HPV) untuk anak perempuan mereka dan meyakinkan mereka tentang keamanan dari vaksin tersebut. Hal ini menjadi kebutuhan mendesak yang perlu dilakukan untuk mengurangi morbiditas dan mortalitas terkait dengan kanker serviks. ${ }^{7}$ Skrining dapat mengurangi insiden dan mortalitas kanker serviks. ${ }^{8}$ Organisasi Kesehatan Dunia (WHO) menyatakan bahwa kanker serviks sebagai penyakit yang dapat dicegah pada perempuan. Kanker serviks dapat timbul tanpa adanya tanda dan gejala, oleh karena itu diagnosis dini dan pengobatan kanker serviks pada perempuan sangat penting untuk menurunkan angka kematian. $^{9}$

Sampai saat ini berbagai tes dan metode telah tersedia untuk diagnosis dini kanker serviks dan pencegahan sekunder. Pap smear adalah salah satu yang paling efektif dan bermanfaat karena merupakan metode yang sederhana, murah, tidak menimbulkan rasa sakit, dan relatif sangat efisien. $^{10,11,12}$ Metode skrining ini telah $79 \%$ berhasil mengurangi kejadian kanker serviks dan $70 \%$ berhasil menurunkan angka kematian akibat kanker jenis ini. ${ }^{13}$ Dalam metode skrining ini, lesi pra-kanker dapat didiagnosis dalam 10 hingga 20 tahun sebelum berkembang menjadi kanker serviks. ${ }^{14}$ Meskipun metode skrining pap smear memiliki kelebihan, tetapi kebanyakan perempuan tidak melakukan tes ini. Berbagai hasil penelitian menunjukkan bahwa perempuan belum memiliki pengetahuan dan kesadaran yang memadai mengenai kanker serviks dan untuk melakukan tes pap smear. ${ }^{15,16,17}$ Pengetahuan dan sikap adalah salah satu faktor prediktif terpenting dalam berperilaku kesehatan dan faktor yang efektif dalam meningkatkan tingkat skrining sebagai wujud pencegahan kanker serviks. ${ }^{13}$

Pengetahuan, sikap dan praktik masyarakat tentang penyakit apapun termasuk kanker serviks dan faktor penyebabnya menawarkan peluang penting sebagai strategi pencegahan dan 
pengendalian penyakit yang komprehensif. ${ }^{14}$ Meningkatnya kasus kanker serviks dapat menambah beban masyarakat dan pemerintah. Oleh karena itu, diperlukan komitmen bersama dalam menurunkan angka kesakitan dan kematian akibat kanker serviks dengan meningkatkan upaya promosi dan preventif guna meminimalkan keterlambatan deteksi pada stadium lanjut. Dengan demikian perlu adanya kesadaran untuk melakukan deteksi dini kanker ${ }^{15}$ serta pemahaman tentang pengetahuan, sikap dan praktik remaja terhadap kanker serviks. ${ }^{16}$

Kesadaran tentang skrining kanker serviks dapat meningkatkan perilaku perempuan yang mengarah pada peningkatan tingkat diagnosis dini dan pengobatan kanker serviks. Penelitian ini bertujuan untuk menganalisis hubungan faktor internal dan eksternal remaja putri dengan perilaku pencegahan kanker serviks.

\section{METODE}

Penelitian ini menggunakan desain studi crosssectional. Dilaksanakan pada bulan AgustusSeptember 2020 di Program Studi Kebidanan Universitas Tribhuwana Tunggadewi Malang dan Fakultas Keperawatan Universitas Citra Bangsa Kupang Nusa Tenggara Timur. Teknik pengambilan sampel yang digunakan adalah simple random sampling.

Populasi dalam penelitian ini adalah seluruh mahasiswi Program Studi Kebidanan Universitas Tribhuwana Tunggadewi Malang dan Fakultas Keperawatan Universitas Citra Bangsa Kupang Nusa Tenggara Timur. Penentuan jumlah sampel dalam penelitian ini menggunakan rumus uji beda proporsi. Berikut rumus nenentuan iumlah samnel $(\mathrm{n})$ :

$$
n=\frac{\left\{Z_{1-\frac{\alpha}{2}} \sqrt{\left(P_{o}\left(1-P_{O}\right)\right)}+Z_{1-\beta} \sqrt{\left(P_{a}\left(1-P_{a}\right)\right)}\right\}^{2}}{\left(P_{a}-P_{o}\right)^{2}}
$$

Keterangan:

$\mathrm{n}=$ besar sampel

$\mathrm{Z}(1-\alpha / 2)=$ derajat kemaknaan pada $\alpha=0,05 ; \mathrm{Z} \alpha$ $=1,96$

$Z(1-\beta)=$ kekuatan uji pada $\beta=0,10 ; Z \beta=1,28$

$\mathrm{Po}=$ proporsi remaja putri yang melaksanakan pencegahan kanker serviks $(\mathrm{P} 1=0,41)$

$\mathrm{Pa}=$ proporsi remaja putri yang tidak melaksanakan pencegahan kanker serviks $(\mathrm{P} 2=$ $0,59)$
Nilai Po dan $\mathrm{Pa}$ diperoleh dari penelitian terdahulu mengenai perilaku pencegahan kanker serviks pada mahasiswi kesehatan yang dilakukan oleh Nur Delima, dkk (2016).

Dengan menggunakan rumus di atas, diperoleh besar sampel minimal yaitu 78 responden. Namun total sampel yang diperoleh dalam penelitian ini yaitu 120 responden. Terdapat tujuh variabel dalam penelitian ini yang terdiri atas variabel dependen dan independen. Variabel dependen yaitu perilaku pencegahan kanker serviks. Variabel independen meliputi usia pertama kali berhubungan seksual, dukungan orang tua, dukungan teman sebaya, budaya, sikap, dan pengetahuan.

Perilaku pencegahan kanker serviks adalah tindakan yang dilakukan oleh subjek penelitian sebagai perwujudan usaha dalam mencegah kanker serviks. Usia pertama kali berhubungan seksual adalah usia dalam tahun ketika subjek penelitian melakukan hubungan seksual pertama kali. Dukungan orang tua adalah respon ayah atau ibu baik secara mental, fisik, atau sosial kepada subjek penelitian dalam melaksanakan pencegahan kanker serviks. Dukungan teman sebaya adalah respon teman yang memiliki usia sama dengan subjek penelitian baik secara mental, fisik, atau sosial kepada subjek penelitian dalam melaksanakan pencegahan kanker serviks. Budaya adalah keyakinan subjek penelitian tentang baik atau buruk, benar atau salah yang berkaitan dengan perilaku pencegahan kanker serviks. Sikap adalah respon subjek penelitian terhadap pemeriksaan pap smear yang dikelompokkan ke dalam dua pernyataan mendukung dan tidak mendukung mengenai sikap cara memelihara kesehatan dan hidup sehat. Pengetahuan adalah jenjang kemampuan subjek penelitian dalam memberikan jawaban secara benar mengenai pengertian kanker serviks, gejala kanker serviks, faktor penyebab kanker serviks, serta pencegahan kanker serviks.

Pengumpulan data dilakukan dengan menggunakan kuesioner secara daring yaitu dengan aplikasi google form. Kendala yang dialami ketika mengumpulkan data menggunakan kuesioner secara daring antara lain kecepatan respon subjek terutama ketika menemukan hal-hal yang tidak dipahami pada saat pengisian kuesioner secara daring, serta koneksi internet yang tidak stabil sehingga 
memerlukan waktu lebih lama untuk bisa mengakses kuesioner. Selain itu, peneliti tidak dapat mengawasi secara langsung proses subjek dalam menjawab pertanyaan kuesioner sehingga tidak dapat dipastikan jawaban yang diberikan merupakan pengetahuan yang dimiliki subjek atau karena menggunakan bantuan lain, seperti internet.

Data yang telah dikumpulkan dianalisis menggunakan analisis jalur (path analysis) dengan menggunakan perangkat IBM SPSS AMOS 25 (Z125-3301-14). Penelitian ini telah memperoleh ijin dari Lembaga Penelitian dan Pengabdian Masyarakat (LPPM) Universitas Tribhuwana Tunggadewi Malang dengan nomor 567/TB-PPM-120/X/2020.

\section{HASIL}

Hasil penelitian menunjukkan bahwa dari 120 subjek, diketahui 85 persen subjek berusia $\geq 20$ 29 tahun, 39 persen beragama Kristen Katolik, 28 persen pendidikan terakhir ibu adalah SMA, 58 persen memiliki ibu dengan pekerjaan ibu rumah tangga, dan 56 persen memiliki pendapatan keluarga di bawah upah minimum wilayah setempat. Tabel 1 menjelaskan bahwa usia pertama kali berhubungan seksual yaitu pada umur 20 tahun, skor dukungan orang tua 40,76, skor dukungan teman sebaya 40,81, skor budaya 39,09, skor sikap 25,06, skor pengetahuan 39,76, dan skor perilaku pencegahan kanker serviks 46,88.

Tabel 1. Hasil analisis univariat variabel penelitian $(n=120)$

\begin{tabular}{lcccc}
\hline & Rerata & Standar deviasi & Minimum & Maksimum \\
\hline Usia pertama kali berhubungan seksual & 20,24 & 3,03 & 18 & 30 \\
Dukungan orang tua & 40,76 & 5,69 & 26 & 50 \\
Dukungan teman sebaya & 40,81 & 5,72 & 27 & 58 \\
Budaya & 39,09 & 4,96 & 30 & 54 \\
Sikap & 25,06 & 4,74 & 8 & 32 \\
Pengetahuan & 39,76 & 4,62 & 30 & 47 \\
Perilaku pencegahan kanker serviks & 46,88 & 3,83 & 38 & 57 \\
\hline
\end{tabular}

Dukungan orang tua, dukungan teman sebaya, budaya, sikap, dan pengetahuan secara signifikan memiliki hubungan yang positif terhadap perilaku pencegahan kanker serviks (Tabel 2). Hal ini memiliki makna bahwa semakin baik dukungan orang tua, dukungan teman sebaya, budaya, sikap, dan pengetahuan maka perilaku pencegahan kanker serviks akan semakin meningkat. Usia berhubungan seksual pertama kali secara signifikan berhbungan negatif terhadap perilaku pencegahan kanker serviks. Hal ini memiliki makna bahwa semakin dewasa usia berhubungan seksual pertama kali maka perilaku pencegahan kanker serviks akan semakin menurun. Hasil analisis pada Tabel 3 menunjukkan bahwa perilaku pencegahan kanker serviks dipengaruhi secara langsung oleh pengetahuan, sikap, dukungan orang tua, dan budaya. Dukungan teman sebaya mempengaruhi perilaku pencegahan kanker serviks melalui pengetahuan. Sedangkan usia berhubungan seksual pertama kali mempengaruhi perilaku pencegahan kanker serviks melalui sikap.

Tabel 2. Hubungan usia pertama kali berhubungan seksual, dukungan orang tua, dukungan teman sebaya, budaya, sikap, dan pengetahuan dengan perilaku pencegahan kanker serviks $(\mathbf{n}=120)$

\begin{tabular}{lcc}
\hline & Koefisien korelasi (r) & P-value \\
\hline Usia berhubungan seksual pertama kali & $-0,24$ & 0,008 \\
Dukungan orang tua & 0,26 & 0,008 \\
Dukungan teman sebaya & 0,07 & 0,071 \\
Budaya & 0,26 & 0,004 \\
Sikap & 0,34 & $<0,001$ \\
Pengetahuan & 0,25 & 0,006 \\
\hline
\end{tabular}

Uji korelasi; signifikan pada $\mathrm{p}<0,05$ 
Setiap peningkatan satu unit pengetahuan akan meningkatkan perilaku pencegahan kanker serviks sebesar 0,16 unit $(b=0,16 ; S E=0,07$; $\mathrm{p}=0,019)$. Setiap peningkatan satu unit sikap akan meningkatkan perilaku pencegahan kanker serviks sebesar 0,23 unit $(b=0,23 ; S E=0,07$; $\mathrm{p}=<0,001)$. Setiap peningkatan satu unit dukungan orang tua akan meningkatkan perilaku pencegahan kanker serviks sebesar 0,12 unit $(b=0,12 ; \mathrm{SE}=0,05 ; \mathrm{p}=0,027)$. Setiap peningkatan satu unit budaya akan meningkatkan perilaku pencegahan kanker serviks sebesar 0,15 unit $(b=0,15 ; \mathrm{SE}=0,06 ; \mathrm{p}=0,020)$.

Tabel 3. Hasil analisis jalur (path analysis)

\begin{tabular}{|c|c|c|c|c|c|c|}
\hline \multirow{2}{*}{\multicolumn{2}{|c|}{$\begin{array}{l}\text { Variabel endogen } \\
\text { Pengaruh langsung }\end{array}$}} & Variabel eksogen & $\mathrm{B}^{*}$ & SE & $\mathrm{p}$ & $\beta^{* *}$ \\
\hline & & & & & & \\
\hline \multicolumn{2}{|c|}{ Perilaku } & Pengetahuan & 0,16 & 0,07 & 0,019 & 0,19 \\
\hline Perilaku & $\longleftarrow$ & Sikap & 0,23 & 0,07 & $<0,001$ & 0,29 \\
\hline Perilaku & $\longleftarrow$ & Dukungan orang tua & 0,12 & 0,05 & 0,027 & 0,18 \\
\hline Perilaku & $\longleftarrow$ & Budaya & 0,15 & 0,06 & 0,020 & 0,19 \\
\hline \multicolumn{7}{|c|}{ Pengaruh tidak langsung } \\
\hline Pengetahuan & $\longleftarrow$ & Dukungan teman sebaya & 0,19 & 0,07 & 0,008 & 0,24 \\
\hline Sikap & $\longleftarrow$ & Usia berhubungan seksual pertama kali & $-0,12$ & 0,06 & 0,053 & $-0,18$ \\
\hline \multicolumn{7}{|l|}{ Model fit } \\
\hline CMIN & \multicolumn{2}{|c|}{$=0,98 ; \mathrm{p}=0,456(>0,05)$} & & & & \\
\hline NFI & \multicolumn{2}{|c|}{$=0,90(\geq 0,90)$} & & & & \\
\hline CFI & \multicolumn{2}{|c|}{$=1,00(\geq 0,95)$} & & & & \\
\hline RMSEA & \multicolumn{2}{|c|}{$=0,00(\leq 0,08)$} & & & & \\
\hline
\end{tabular}

Selanjutnya pengetahuan dipengaruhi oleh dukungan teman sebaya dan sikap dipengaruhi oleh usia berhubungan seksual pertama kali. Setiap peningkatan satu unit dukungan teman sebaya akan meningkatkan pengetahuan sebesar 0,19 unit $(b=0,19 ; S E=0,07 ; p=0,008)$. Setiap peningkatan satu unit usia berhubungan seksual pertama kali akan menurunkan sikap sebesar 0,12 unit $(b=-0.12 ; S E=0,06 ; p=0,053)$.dari hasil analisis pada Tabel 3 diketahui bahwa jalur yang memiliki nilai paling signifikan adalah pengaruh langsung sikap terhadap perilaku pencegahan kanker serviks dengan nilai $\mathrm{p}<0.001$.
Gambar 1 menunjukkan nilai dari model struktural setelah dilakukan estimasi menggunakan software IBM SPSS AMOS 20. Indikator kesesuaian model analisis jalur seperti pada Tabel 3 juga menunjukan adanya goodness of fit measure (pengukuran kecocokan model), yaitu diperoleh hasil fit index (indeks kecocokan) CMIN sebesar 0,98 dengan $\mathrm{p}=0.456$ $>0.05$; NFI $=0.90 \geq 0.90$; CFI $1.00 \geq 0.95$; RMSEA $=0.00 \leq 0.08$, artinya model empirik telah memenuhi kriteria yang ditentukan dan dinyatakan sesuai dengan data empirik.

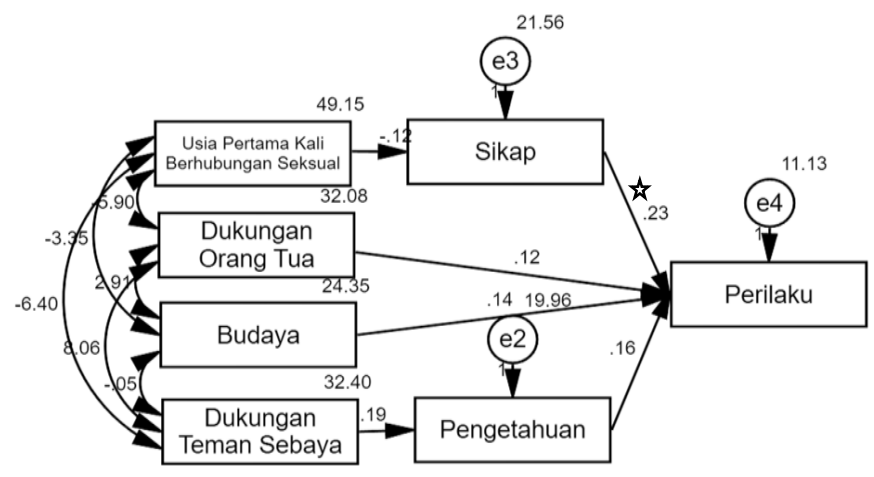

Gambar 1. Model struktural analisis jalur

Jurnal Kesehatan Reproduksi, 11(2), 2020 


\section{PEMBAHASAN}

\section{Pengaruh sikap terhadap perilaku pencegahan kanker serviks}

Dalam penelitian ini, sikap merupakan faktor yang mempengaruhi perilaku pencegahan kanker serviks dengan tingkat signifikansi paling tinggi. Sikap yang positif serta deteksi dini terhadap kanker serviks sangat mendukung perempuan untuk melaksanakan skrining kanker serviks. Salah satu hambatan yang dapat menjadi penghalang bagi perempuan untuk melakukan skrining yaitu sikap negatif yang memandang bahwa tidak diperlukan adanya skrining untuk deteksi kanker serviks. Terbentuknya sikap dipengaruhi oleh adanya rangsangan berupa pengetahuan yang dimiliki oleh perempuan terkait dengan kanker serviks yang kemudian akan menghasilkan sikap serta perilaku.

Sebagian besar perempuan menunjukkan sikap positif terhadap skrining kanker serviks. Sebagai contoh, perempuan menyadari bahwa mereka berisiko terkena kanker serviks yang diyakini sebagai penyakit yang parah dan diagnosis penyakit ini secara dini sangat membantu dalam pengobatan penyakit. Baik sikap perempuan maupun skrining terhadap kanker serviks merupakan hal yang sama pentingnya. Persepsi perempuan tentang risiko kanker serviks berkaitan dengan niat mereka untuk pergi ke layanan kesehatan dan melakukan skrining. ${ }^{19}$ Penelitian sebelumnya menunjukkan bahwa faktor sikap tidak merasa rentan terhadap kanker serviks dan memiliki pengetahuan yang terbatas tentang penyakit ini mempengaruhi penggunaan layanan. ${ }^{19}$ Perempuan yang memiliki pengetahuan dan sikap positif mengenai kanker serviks memberikan peluang dalam peningkatan program skrining kanker serviks. Oleh karena itu, jika perempuan memiliki lebih banyak kesempatan untuk melakukan skrining, maka kesempatan untuk mendeteksi kanker serviks dan melakukan tindakan pencegahan lebih dini akan lebih besar.

Namun dalam beberapa penelitian ditemukan bahwa ketika kesempatan untuk skrining diberikan kepada perempuan, ada hambatan lain yang dilaporkan seperti ketakutan akan hasil diagnosis kanker serviks yang positif, ketakutan lain yang terkait dengan prosedur skrining, dan ketakutan ketika dilakukan pemeriksaan pada vagina. ${ }^{20}$ Oleh karena itu program harus dirancang untuk mengatasi hal ini dan memberikan pengobatan bagi mereka yang didiagnosis menderita kanker serviks. Program kesadaran dan pencegahan kanker serviks harus terus diupayakan untuk mempengaruhi persepsi perempuan tentang kanker serviks dan skrining. Sikap positif terhadap pemeriksaan diri menunjukkan alternatif peluang untuk mengoptimalkan cakupan pemeriksaan kanker serviks. ${ }^{21}$ Sikap positif dalam skrining kanker serviks sangat penting untuk mendukung kesediaan dalam menjalani skrining sebagai bentuk perilaku pencegahan kanker serviks. ${ }^{22}$ Studi lain juga mengemukakan bahwa meskipun perempuan memiliki tingkat pengetahuan yang rendah mengenai kanker serviks, namun sikap mereka cukup baik terhadap skrining kanker serviks. $^{23}$

\section{Pengaruh pengetahuan terhadap perilaku pencegahan kanker serviks}

Pada penelitian ini subjek yang memiliki latar belakang pendidikan kesehatan memiliki pengetahuan tingkat sedang terkait perilaku pencegahan kanker serviks. Namun demikian, masih terdapat beberapa subjek yang berperilaku kurang dalam pencegahan kanker serviks. Pendidikan kesehatan secara luas kepada perempuan diperlukan untuk meningkatkan pengetahuan mereka, terutama dengan penekanan pada fakta bahwa vaksinasi dan skrining merupakan standar baru untuk pencegahan kanker serviks, karena vaksinasi HPV mencegah sebagian besar kanker serviks dan skrining dapat mendeteksi lesi prakanker yang dapat dapat dikurangi dengan pengobatan. Selain itu, pemanfaatan layanan media seperti televisi, koran, dan radio berdampak besar dalam peningkatan pengetahuan. Pengetahuan perempuan tentang kanker serviks dan kesadaran tentang pencegahannya merupakan faktor kunci yang menentukan pemanfaatan layanan skrining. ${ }^{24}$

Tingkat pendidikan memegang peranan penting dalam pengetahuan. Mahasiswa yang memiliki kebiasaan membicarakan kanker dengan keluarga atau teman memiliki pengetahuan yang lebih tinggi tentang kanker serviks dibandingkan mahasiswa yang tidak membicarakan kanker 
dengan siapapun. Mahasiswa yang memiliki tingkat pengetahuan tinggi dapat disebabkan oleh keterpaparan terhadap materi, misalnya sudah pernah membaca tentang kanker serviks ini di kelas mereka. ${ }^{25}$ Sebuah studi menyoroti pengetahuan yang tidak memadai tentang kanker serviks dan skrining di antara profesi kesehatan. Program pendidikan kedokteran dan keperawatan yang berkelanjutan harus dimulai di tingkat rumah sakit, misalnya dengan mengadakan seminar yang mendidik masyarakat dengan menyoroti pentingnya skrining sehingga dapat meningkatkan perilaku pencarian kesehatan pada perempuan. Penekanan pengetahuan kanker serviks perlu menjadi kurikulum yang diajarkan dalam pendidikan sarjana. Melalui pendidikan petugas kesehatan yang tepat, maka beban kanker serviks dapat dikurangi. ${ }^{26}$ Selain itu, biaya tinggi dan kurangnya pengetahuan tentang vaksinasi HPV menjadi hambatan terbesar terselenggaranya vaksinasi sebagai tindakan pencegahan, sehingga penting untuk meningkatkan kesadaran akan manfaat vaksinasi HPV dan menurunkan biaya vaksin agar lebih terjangkau. ${ }^{27}$

Studi ini mengonfirmasi hasil studi yang menilai pengetahuan dan sikap terhadap skrining kanker serviks pada mahasiswi di Botswana, yang menunjukkan bahwa seluruh subjek penelitian memiliki pengetahuan tentang kanker serviks dan skrining. Tingkat kesadaran yang tinggi ini dapat disebabkan oleh status pendidikan subjek dan pengaruh media cetak dan sektor kesehatan dalam menumbuhkan kesadaran akan penyakit ini di kalangan masyarakat. ${ }^{28}$

\section{Pengaruh dukungan orang tua terhadap perilaku pencegahan kanker serviks}

Dukungan keluarga salah satunya adalah dukungan orang tua dalam pencegahan kanker serviks. Dalam penelitian ini diketahui bahwa dukungan orang tua memiliki peran penting bagi remaja dalam pencegahan kanker serviks. Lima penelitian tentang pemahaman orang tua mengenai HPV dan kanker serviks menunjukkan bahwa rata-rata 74 persen orang tua dapat mengidentifikasi dengan benar hubungan antara HPV dan kanker serviks. Namun perlu hasil dari berbagai penelitian untuk mendapatkan kesimpulan yang kuat mengenai hubungan antara pengetahuan dan ketersediaan vaksin HPV. ${ }^{34}$ Orang tua memainkan peran utama dalam keluarga terkait dengan kesehatan anak perempuannya. Para ibu yang memiliki anak menyatakan bahwa anak merupakan aspek terpenting dalam kehidupan mereka. Menjaga kesehatan anak sangat penting untuk masa depan anak itu sendiri, salah satunya melalui dukung untuk mendapatkan tes pap smear.

Hal yang menarik untuk diketahui adalah perubahan sikap dan perilaku orang tua terkait informasi HPV dan vaksinasi HPV yang terus membanjiri media. Informasi mengenai HPV onkogenik yang merupakan penyebab kanker serviks akan terus berkembang seiring dengan strategi skrining kanker serviks yang bergerak menuju tes HPV primer. Hal ini akan meningkatkan pengetahuan masyarakat umum mengenai kanker serviks. Masalah biaya seharusnya tidak menjadi penghalang karena harga vaksin terus menurun. Demikian juga ketika strategi pencegahan berbasis populasi berhasil maka akan sangat menarik untuk melihat sikap orang tua dalam menyetujui program vaksinasi berbasis sekolah. Informasi tentang seberapa lama vaksin dapat bertahan dan gejala yang ditimbulkan akan diketahui secara jangka panjang sehingga perlu terus dilakukan pemantauan tentang sikap orang tua. ${ }^{29}$

\section{Pengaruh budaya terhadap perilaku pencegahan kanker serviks}

Dalam penelitian ini ditemukan bahwa budaya diyakini oleh subjek penelitian berpengaruh terhadap perilaku kesehatan dalam menjaga kebersihan organ reproduksi serta pencegahan kanker serviks. Salah satu budaya yang diyakini adalah pemberian vaksin HPV khusus untuk perempuan yang sudah menikah. Budaya dipengaruhi oleh masyarakat sekitar dan orang tua. Budaya dan adat istiadat Timur yang kental di Indonesia telah membentuk sikap dan persepsi yang dapat menjadi penghalang bagi perempuan untuk membuka diri terhadap tenaga medis profesional yang mampu melindungi kesehatan reproduksi. Studi lain menunjukkan hubungan antara budaya dan perilaku pencegahan kanker serviks yang cenderung mempertahankan budaya dan bahasa yang kuat dengan masyarakat tradisional. Perilaku ini cenderung mempengaruhi gaya hidup serta keyakinan dan praktik perawatan kesehatan. Hal ini mungkin dapat menjelaskan mengapa beberapa subkelompok Asia tertinggal dibandingkan kelompok etnis lain dalam mencari dan 
mendapatkan tes skrining dasar seperti pap smear. ${ }^{30}$

Hasil penelitian ini menunjukkan bahwa perbedaan budaya, etnis, dan ras bukanlah faktor yang terkait dengan perilaku pencegahan dan pengendalian kanker serviks, misalnya skrining dan vaksinasi HPV. Perbedaan latar belakang budaya serta kebutuhan dan asert dalam suatu komunitas menjadi hal yang penting untuk dipertimbangkan dalam menyusun strategi untuk mengatasi hambatan dan sebagai motivasi agar intervensi yang dilakukan di masyarakat berhasil. Perempuan dengan keyakinan yang benar tentang penyebab kanker serviks dan pencegahannya akan menjadi hal yang sangat baik bagi dirinya. Salah satu implikasi dari temuan ini adalah program yang ada sebelumnya mungkin tidak memperhitungkan pengaruh budaya pada perilaku kesehatan sehingga perlu kajian tentang kebutuhan yang tepat sebelum program dirancang dan dilaksanakan. Program edukasi harus dirancang untuk mengoreksi keyakinan negatif karena untuk mencegah transfer pengetahuan yang kurang tepat ke dalam suatu perilaku. ${ }^{31}$

\section{Pengaruh dukungan teman sebaya terhadap pengetahuan}

Teman adalah orang yang paling berpengaruh selama masa remaja dan dukungan teman sebaya dapat membantu meningkatkan cakupan skrining dikalangan perempuan muda. ${ }^{32}$ Selama masa remaja, teman sebaya memainkan peran penting dalam mengubah kepribadian, sikap, dan perilaku seseorang. ${ }^{33}$ Oleh karena itu, berjalannya program edukasi kanker serviks bersama-sama dengan kegiatan kelompok sebaya mungkin akan lebih efektif pada kelompok remaja. Penelitian juga menunjukkan bahwa remaja lebih mungkin untuk mengubah perilaku mereka apabila menerima pesan kesehatan dari teman sebaya yang menghadapi masalah dan tekanan yang sama. ${ }^{34}$ Salah satu sumber informasi kesehatan reproduksi yang penting bagi remaja adalah teman sebayanya. Beberapa penelitian telah menunjukkan dampak positif dukungan sebaya terhadap peningkatan pengetahuan.

Penelitian ini mengonfirmasi hasil penelitian sebelumnya tentang dukungan sebaya yang efektif dalam meningkatkan pengetahuan pada perempuan. Pendekatan seperti ini merupakan hasil studi yang sangat bermanfaat dalam penyebaran informasi tentang HPV dan kanker serviks pada remaja. Metode berbeda dalam menggunakan teman sebaya telah dilakukan melalui teknik penyampaian formal dalam suatu kelas. Keunggulan metode ini adalah kemampuan untuk menjangkau partisipan dalam jumlah besar dan dalam waktu singkat dengan sumber daya yang minimal.

Strategi ini berpeluang besar untuk meningkatkan pengetahuan tentang kanker serviks karena para remaja dapat mendiskusikan informasi yang diterima dengan anggota keluarga dan dengan teman yang tidak bersekolah. Penggunaan kata kunci dapat meningkatkan daya ingat dan memberikan efek positif melalui penekanan fakta krusial yang harus diketahui. Dukungan teman sebaya adalah strategi yang efektif untuk meningkatkan pengetahuan dengan cepat dan optimal pada kelompok remaja. Strategi ini dapat direkomendasikan ke seluruh instansi pendidikan agar semua informasi penting tersampaikan ke kelompok sasaran. ${ }^{35}$

\section{Pengaruh usia pertama kali melakukan hubungan seksual terhadap sikap}

Penelitian ini melaporkan bahwa semakin tinggi usia perempuan maka semakin rendah sikap remaja terhadap pencegahan kanker serviks. Sebagian besar penelitian menunjukkan bahwa peningkatan jumlah pasangan dan usia muda saat pertama kali melakukan hubungan seksual dapat meningkatkan peluang mengalami kanker serviks. Faktor yang dapat mempengaruhi sikap dalam mencegah kanker serviks antara lain pengaruh lingkungan, keterbatasan pengetahuan, tradisi atau budaya, media massa, serta emosi subjek penelitian.

Mereka yang melakukan hubungan seksual secara dini juga berpeluang untuk hamil pada usia dini. Selain usia dini saat pertama kali melakukan hubungan seksual, melahirkan dini juga dikaitkan sebagai faktor risiko karsinogenesis serviks dan dikaitkan dengan trauma serviks. Risiko kanker serviks juga akan bergantung pada riwayat seksual pasangan tersebut selain perilakunya sendiri. ${ }^{36}$ Perempuan yang melakukan hubungan seksual pada masa remaja memiliki peluang tiga kali lebih besar untuk terkena kanker serviks. Pada kelompok usia remaja, sel mukosa serviks masih belum 
matang dan akan lebih sensitif terhadap perubahan yang selanjutnya menjadi kondisi abnormal. Sikap remaja yang rendah dalam mencegah kanker serviks tentunya akan berdampak buruk pada kesehatan reproduksi mereka nantinya.

\section{KESIMPULAN}

Pengetahuan, sikap, dukungan orang tua, dan budaya mempengaruhi perilaku pencegahan kanker serviks secara langsung pada remaja. Dukungan teman sebaya mempengaruhi perilaku pencegahan kanker serviks melalui pengetahuan. Usia berhubungan seksual pertama kali mempengaruhi perilaku pencegahan kanker serviks melalui sikap.

\section{SARAN}

Institusi pelayanan kesehatan disarankan untuk secara berkala melaksanakan kegiatan sosialisasi, konseling terkait kanker serviks, dan deteksi dini menggunakan metode Inspeksi Visual Asam Asetat (IVA). Kegiatan ini disarankan untuk melibatkan orang tua agar promosi kesehatan pencegahan kanker serviks dapat berjalan lebih optimal. Perempuan usia subur disarankan untuk melaksanakan pemeriksaan IVA serta aktif dalam mengakses informasi mengenai upaya pencegahan kanker serviks. Sebagai calon tenaga kesehatan professional, diharapkan mahasiswa kesehatan dapat secara konsisten dalam melaksanakan promosi pencegahan kanker serviks dalam kegiatan sehari-hari sebagai wujud nyata pengamalan ilmu yang telah didapatkan. Kegiatan akademik di bidang kesehatan disarankan untuk rutin melaksanakan edukasi ke masyarakat, khususnya remaja putri, mengenai pencegahan kanker serviks.

\section{UCAPAN TERIMA KASIH}

Peneliti mengucapkan terimakasih kepada Universitas Tribhuwana Tunggadewi Malang dan mitra peneliti Universitas Citra Bangsa Kupang atas kesempatan yang diberikan dalam melaksanakan kegiatan penelitian. Terimakasih kepada responden penelitian, mahasiswi Universitas Tribhuwana Tunggadewi dan Universitas Citra Bangsa atas partisipasinya dalam kegiatan penelitian.

\section{DAFTAR PUSTAKA}

1. Arbyn M, Weiderpass E, Bruni L, de Sanjosé S, Saraiya M, Ferlay J BF. Estimates of incidence and mortality of cervical cancer in 2018: a worldwide analysis. Lancet Glob Heal. 2020;8(2):e191-203.

2. Ferlay J, Soerjomataram I, Ervik M, Dikshit R, Eser S MC. Cancer Incidence and Mortality Worldwide: IARC Cancer Base No. 11. Lyon. International Agency for Research on Cancer. 2013.

3. Catarino R, Petignat $\mathrm{P}$, Dongui G, Vassilakos P. Cervical cancer screening in developing countries at a crossroad: Emerging technologies and policy choices. World J Clin Oncol. 2015;6(6):281-90.

4. WHO. Cervical cancer estimated incidence, mortality and prevalence worldwide in 2012, international agency for research on cancer. World Health Organization. 2012.

5. Korkut Y. Assessment of knowledge , attitudes, and behaviors regarding breast and cervical cancer among women in western Turkey. 2019;

6. de Sanjose, Serrano B, Castellsague X, Brotons M, Munoz J BL. Human Papillomavirus (HPV) and Related Cancers in the Global Alliance for Vaccines and Immunization (GAVI) Countries. 2012.

7. Gamaoun R. Awareness and knowledge about cervical cancer prevention methods among Tunisian women. J Prev Med Hyg. 2018;59(1):E30-5.

8. Mishra GA, Pimple SA, Shastri SS. An overview of prevention and early detection of cervical cancers. Indian $\mathbf{J}$ Med Paediatr Oncol. 2011;32(3):125-32.

9. Šarenac T, Mikov M. Cervical cancer, different treatments and importance of bile acids as therapeutic agents in this disease. Front Pharmacol. 2019;10(JUN):1-29.

10. Oo O, Ma O, Pi U. Cervical Cancer Awareness and Preventive Practices: A Challenge for Female Urban Slum Dwellers in Lagos , Nigeria Résumé. 2012;16(March):75-82.

11. Roy B, Tang TS. Cervical Cancer Screening in Kolkata, India: Beliefs and 
Predictors of Cervical Cancer Screening Among Women Attending a Women's Health Clinic in Kolkata, India. 2008;253-9.

12. Ghojazadeh M, Azar ZF, Saleh P, Naghavi- M, Azar NG. Knowledge and Attitude of Iranian University Students toward Human Papilloma Virus. 2012;13:6115-9.

13. Gamarra CJ. Knowledge, attitudes and practice related to Papanicolaou smear test among Argentina $\hat{a} €^{\mathrm{TM}} \mathrm{s}$ women. 2005;(May).

14. Mosavel M. Health promotion and cervical cancer in South Africa: why adolescent daughters can teach their mothers about early detection. 2011;27(2):157-66.

15. Aweke YH, Ayanto SY, Ersado TL. Knowledge, attitude and practice for cervical cancer prevention and control among women of childbearing age in Hossana Town, Hadiya zone, Southern Ethiopia: Community-based crosssectional study. 2017;1-18.

16. Koo MM, Swann R, McPhail S, Abel GA, Elliss-Brookes L, Rubin GP, et al. Presenting symptoms of cancer and stage at diagnosis: evidence from a crosssectional, population-based study. Lancet Oncol [Internet]. 2020;21(1):73-9. Available from: http://dx.doi.org/10.1016/S14702045(19)30595-9

17. Mapanga W, Girdler-brown B, Singh E. Knowledge, attitudes and practices of young people in Zimbabwe on cervical cancer and HPV, current screening methods and vaccination. 2019;1-14.

18. Murti B. Desain dan ukuran sampel untuk penelitian kesehatan. Edisi 2. Yogyakarta: Gadjah Mada University Press; 2014.

19. Nyambe A, Kampen JK, Baboo SK, Hal $G$ Van. Knowledge , attitudes and practices of cervical cancer prevention among Zambian women and men. 2019;1-15.

20. Lyimo FS, Beran TN. accessibility factors associated with uptake of cervical cancer screening among women in a rural district of Tanzania : Three public policy implications. BMC Public Health. 2012;12(1):22.

21. Lim JNW, Lecturer S, Leader C, Health
HP, Science M. Barriers to utilisation of cervical cancer screening in Sub Sahara Africa : a systematic review. 2016;

22. Tekle T, Wolka E, Nega B, Kumma WP, Koyira MM. Knowledge, attitude and practice towards cervical cancer screening among women and associated factors in hospitals of Wolaita zone, southern Ethiopia. Cancer Manag Res. 2020;12:993-1005.

23. Mengesha A, Messele A, Beletew B. Knowledge and attitude towards cervical cancer among reproductive age group women in Gondar town, North West Ethiopia. BMC Public Health. 2020;20(1):1-10.

24. Siddharthar J, Rajkumar B, Deivasigamani K. Knowledge , Awareness and Prevention of Cervical Cancer among Women Attending a Tertiary Care Hospital in Puducherry, India. 2014;8(6):8-10.

25. Poudel K. Analyzing Awareness on Risk Factors, Barriers and Prevention of Cervical Cancer among Pairs of Nepali High School Students and Their Mothers. 2019;

26. Ali SF, Ayub S, Manzoor NF, Azim S, Afif M, Akhtar N, et al. Knowledge and Awareness about Cervical Cancer and Its Prevention amongst Interns and Nursing Staff in Tertiary Care Hospitals in Karachi , Pakistan. 2010;5(6):1-6.

27. Touch S, Oh J. Knowledge, attitudes, and practices toward cervical cancer prevention among women in Kampong Speu Province, Cambodia. 2018;1-8.

28. Tapera R, Manyala E, Erick P, Maswabi TM, Letsholo B, Mbongwe B. Knowledge and Attitudes towards Cervical Cancer Screening amongst University of Botswana Female Students. 2017;18:2445-50.

29. Trim K, Nagji N, Elit L, Roy K. Parental Knowledge , Attitudes, and Behaviours towards Human Papillomavirus Vaccination for Their Children: A Systematic Review from 2001 to 2011. 2012;2012.

30. Scarinci IC, Garcia FAR, Kobetz E, Partridge EE, Brandt M, Bell MC, et al. NIH Public Access. 2011;116(11):253142.

31. Rimande-joel R, Ekenedo GO. Knowledge , Belief and Practice of 
Cervical Cancer Screening and Prevention among Women of Taraba, North-East Nigeria. 2019;20:3291-8.

32. Yamaguchi N, Tsukamoto Y, Shimoyama H, Nakayama K, Misawa S. Effects of peer education interventions aimed at changing awareness of cervical cancer in nursing students. :32-42.

33. Adhikari R, Tamang J. Premarital Sexual Behavior among male college students of. 2009;9:1-9.

34. Abdi F, Simbar M. The Peer Education Approach in Adolescents- Narrative
Review Article. 2013;(November).

35. Sadoh AE, Okonkwo C, Nwaneri DU. Effect of Peer Education on Knowledge of Human Papilloma Virus and Cervical Cancer among Female Adolescent Students in Benin City, Nigeria. 2018;84(1):121-8.

36. Herrero R, Meijer CJ, Shah K, Franceschi S, Louie KS, Sanjose S De, et al. Early age at first sexual intercourse and early pregnancy are risk factors for cervical cancer in developing countries. 2009;1191-7. 